After 22 and $72 \mathrm{hr}$. of incubation, at $p \mathrm{H} 6.5$ and $36^{\circ} \mathrm{C}$, under aseptic conditions, no chitinolytic activity could be detected.

(2) Absence of chitinolytic bacteria in the digestive tract. Four larvæ, grown on dried insects, were cleaned and aseptically dissected in a sterile chamber. The digestive tracts were ground in a sterile mortar and suspended in $2 \mathrm{ml}$. sterile distilled water. $1 \mathrm{mgm}$. of excreta of larvæ was similarly suspended in $2 \mathrm{ml}$. distilled water.

The suspensions were then added to a sterile agar-agar medium containing finely powdered chitin, and plated in Petri dishes ${ }^{6}$. After ten days, no chitinolytic bacteria could be detected: no typical clarification of the medium, such as that usually observed with all chitinolytic bacteria of different sources $^{4,8}$, was noticed. Digestive tracts and also excreta are particularly poor in micro-organisms, and seem to be entirely devoid of chitinolytic bacteria.

(3) Chitin balance in the diet of larva reared in controlled conditions. When reared on a diet consisting of dried insects (adults of Musca sp., Palomena prasina and Doryphora decemlineata), larvæ of $A$. verbasci are able to utilize a maximum of 30 per cent (in dry weight) of the available diet. Two sets of experiments were carrjed out with larvæ reared for three months on a diet of a known content of chitin, at $28^{\circ} \mathrm{C}$. and 50 per cent relative humidity. One control experiment consisted of exposing the same food in the same incubator without larvæ.

In one experiment, chitin was estimated by purification of the material, using the method of Black and $\mathrm{Schwartz}^{7}$, the residue being weighed as pure chitin. The loss of chitin in the food seemed rather important (28 per cent with dried Musca and Palomena as diet, 8.5 per cent with Doryphora). But this method was found afterwards to be quite unsatisfactory in this particular case owing to the fact that purification is not completed (some proteins remain unhydrolysed) and the excreta, being of a very finely powdered material, are not easily retained during manipulations.

In a second experiment, chitin was estimated by purification of the material with 6 per cent potassium hydroxide at $100^{\circ} \mathrm{C}$. for $2 \mathrm{hr}$.; $N$ hydrochloric acid at $20^{\circ} \mathrm{C}$. for $2 \mathrm{hr}$.; again 6 per cent potassium hydroxide at $100^{\circ} \mathrm{C}$. for $2 \mathrm{hr}$.; $1: 1,000$ potassium permanganate at $60^{\circ} \mathrm{C}$. for $20 \mathrm{~min}$.; sodium metabisulphite; hot water, alcohol, ether. These different chemical treatments and the washings were performed in centrifuge tubes, the residue being contrifuged after each treatment for a long time, to prevent any loss of small particles. Estimation of chitin in the final residue was by nitrogen determination (Kjeldahl method).

In these conditions, the loss of powdered material was considerably reduced. The difference in chitinnitrogen between controls and a diet consisting of dried Palomena prasina on which fifty larvæ were reared for three months reached 4 per cent only, this value being within the normal limits of error of the method. Thus chitin is not digested and can be nearly completely recovered in a controlled diet, although the cuticles of the dried insects are partially destroyed and reduced to powder by the larvæ.

Hence we conclude that, using an adequate method for the estimation of ehitin balance in dried insects eaten by Anthrenus verbasci larvæ, no significant loss of chitin could be observed. The digestive tracts of these larvæ are devoid of chitinase and of chitinolytic micro-organisms. Such larvæ are unable to digest chitin, although there is a high content of chitin in their usual diet.

Institut Léon Fredericq Chimie Physiologique, Université de Liège. July 22.

1 Karrer, P., and Hofmann, A., Helv. Chim. Acta, 12, 616 (1929). 2 Tracey, M. V., Nature, 167, 776 (1951).

3 Tracey, M. V., 2nd Int. Congr. Biochem., Paris, Résumé dēs Comm., 242 (1952).

4 Jeuniaux, Ch. Mém. Acad. Roy, Belg., Classe Sci., 28, fasc. 7 (1954).

${ }^{5}$ Jeuniaux, Ch., Arch. internat. Physiol. Biochem. (in the press).

- Jeuniaux, Ch., Physiol. Comparata Oecol. (in the press).

Black, M. M., and Schwartz, H. M., Analyst. 75. 186 (1950).

\section{Supra-Sternal Ossicles in Primates other than Man}

Dr. G. T. Astrey's communication ${ }^{1}$ prompts me to record a further example of supra-sternal ossicles in primates, this time in Perodicticus potto. The specimen, which was the prepared skeleton of a young animal, showed a supra-sternal ossicle on the right side only, contributing to the articular surface for the clavicle (Fig. 1). The ossicle on the left side was presumably lost during preparation. From a

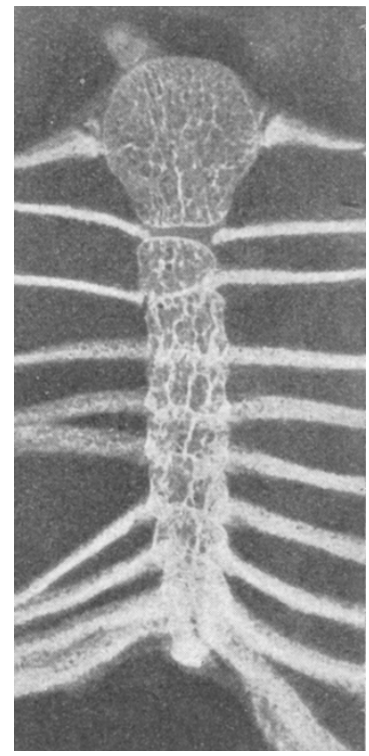

Fig. 1. Radiograph of the sternum of an immature Perodicticus potto showing the presence of a supra-sternal ossicle on the

comparison with the adult sternum, it would appear that in Perodicticus the supra-sternal ossicles ere responsible for the prominent antero-lateral angles of the manubrium sterni and thus for the deep supra-sternal notch. It is possible that they are a regular feature in the development of th, sternum in this animal. It must not be forgotten, however, that the supra-sternal notch in man is considerably shallower in the newborn than in the adult, though supra-sternal ossicles do not seem to be a constant feature here.

Anatomy Department,

D. V. Davies

St. Thomas's Hospital Medical School,

London, S.E.1. Sept. 27.

${ }^{1}$ Nature, 176, 608 (1955). 